\title{
Crime, Street Vendors and the Historical Downtown in Post- Giuliani Mexico City
}

\author{
Rodrigo Meneses Reyes ${ }^{*}$
}

\author{
División de Estudios Jurídicos, Centro de Investigación y Docencia Económicas, Mexico
}

\begin{abstract}
This article endeavors to go deeply into the recent transformations that have taken place in the regulation of street-level economic and business activities in Mexico City. It draws upon data collected during the course of a threeyear research project carried out from 2007 to 2009, a specific timeframe when the urban authority deployed different legal and repressive strategies in order to 'clean-up' the streets of the city's downtown areas, in keeping with the Giuliani Group's advice. This paper intends to clarify two different dynamics: (a) how the urban authorities went about applying Giuliani's advice to clean up the streets, and (b) the consequences these initiatives may have on the historical downtown core. My principal task is to offer a tentative insight into whether the incorporation of Giuliani's repressive approach to urban planning has affected a specific urban space where, for decades, street-level economic, business and trade activities have been intimately interrelated with the creation of a city's street culture. Research findings suggest that in those countries where street economic activities constitute a die-hard method of eking out one's sustenance, the relation between order and crime may be more porous and indeterminate than is recognized and acknowledged by the majority of sociolegal studies that have, over the course of time, developed around this topic.
\end{abstract}

Keywords: Urban regulation, street-level economic activities, crime prevention.

\section{A. INTRODUCTION}

The notion that any minor social disorder, if tolerated, will lead to an environment that is likely to attract crime, does exert widespread influence on contemporary deliberations of how the police should control the city (Harcourt and Ludwig, 2006). Nevertheless, the question of how this impression is maintained, promoted, enforced or interpreted is among the most hotly contested issues for the sociolegal debate today (Harcourt, 2003; Heinkle and Weisburd, 2008). To be sure, there are several angles wherewith to explain this controversy. For some authors, the policies for control which are designed and implemented using the 'zero tolerance' approach, similar to the ones deployed by Giuliani in New York City, significantly increased the probability of feeling unsafe (Heinkle and Weisburd, 2008). While, for others, manifestations of disorder and delinquency both warrant being policed in similar ways, they obey a similar logic (Sampson \& Raudenbush, 1999). Accordingly, some authors have suggested that "the ambiguity of [this type of initiatives] should be addressed with efforts to define disorder with greater accuracy through the systematic study of the people who may increase or decrease safety" (Duneier, 2001:298-315).

Such indeterminacy, I suggest, forces us to empirically answer a permanent and often tautological

*Address correspondence to this author at the División de Estudios Jurídicos, Centro de Investigación y Docencia Económicas, Mexico;

Tel: 57279800, Ext. 2253; E-mail: rodrigo.meneses@cide.edu question: what category of behaviors does the police typically treat as an urban disorder? (Kubrin, 2008). As in many other societies, the power to define what is disorder and what is an offense against urban order depends largely on time and place (Gurr, 1976:141). However, it seems necessary to understand how this repressive approach to urban planning has brought to light contemporary issues of social (dis)order and, perhaps most importantly, has contributed in reconfiguring the legal position of certain street-level activities into a given regulatory network, particularly in those places where 'disorder' represents not a marginal or haphazard activity, but an all-encompassing means for a human being to earn a living. This article addresses this topic, by discussing the recent transformations that have taken place in the regulation of street vending in Mexico City: a street-level activity that has myopically been identified as a form of urban disorder, as well as a visible and public expression of illegality. I shall draw on data produced in the course of a three-year research project carried out from 2007 to 2009, which was the specific timeframe during which the urban authority deployed different legislative and legal enforcement strategies in order to 'clean-up' the streets of the city's downtown areas, following the Giuliani Group's advice. ${ }^{1}$ This paper is intended to clarify two different dynamics: (a) how urban authorities

\footnotetext{
${ }^{1} \mathrm{~A}$ revision of the context in which Guliani was hired by Mexico City authorities may be read in (Davis,2007; Mitchell \& Beckett,2008; Campesi,2010). As discussed later, Giuliani's advisement consisted in a document with 146 proposals on crime policy and the reform of police powers, available at: http://www.elsemanario.com.mx/doc/ReporteGiuliani.pdf [retrieved on 16.04.12].
}

〔C 2013 Lifescience Global 
applied Giuliani's advice to clean up the streets, and (b) the consequences of the cleanup on the urban order. My principal task is to offer a tentative answer to whether the incorporation of Giuliani's highly repressive approach to urban planning has affected Mexico City, a specific urban space where, for decades, street-level economic activities have performed an integral role in the creation of a city's street culture ${ }^{2}$.

To illustrate these dynamics, I draw from a collection of official statistics and reports concerning street vending and criminal activities reported in the city's downtown area. This source has been complemented by in-depth interviews with street-level police officers and street vendors in the city's downtown areas. This material constituted a qualitative inquiry that comprised 45 in-depth interviews that were developed in the city's downtown areas between street police officers ( $p$ ) and street vendors (sv). Specifically, the research engaged with the voices of the then unauthorized street vendors. ${ }^{3}$ All the interviews were done face-to-face, in the public space in an open and non-structured manner. Candidates for interviews were selected based on convenience and availability. For instance, vendors who were facing a direct interaction with police officers were not asked to participate in the study. The results have been cross-referenced to better compare the different perspectives. Central ideas are intermittently interspersed with quotes from these interviews.

Research findings not only suggest the importance of a careful focus on 'how' broken-windows policing programs are implemented, as suggested by Heinkle and Weisburd (2008), but they also suggest that in those countries where street economic activities represent a predominant means of earning money, the relation between order and crime may be more porous and indeterminate than is recognized by the majority of sociolegal studies developed around this topic.

\footnotetext{
'Just as any other term that includes the 'culture' concept, the term 'street culture' has been used in social science to mean different things. Its definition ranges from the behavior that certain social groups exhibit (criminal gangs, juvenile identities) to the appearance and activities of those who live on the sidewalks. Nevertheless, within the limits of this work, the term is used to mean the street as a public arena, where certain changes in the regulation of the everyday life and the social response to these changes take place, as proposed by (Wang, 1998:35).

${ }^{3}$ Following ethnographic accounts on 'hard to reach populations' (James,2007:370-371), interviews here presented were gained through a 'snowball' research strategy via initial contacts with other street vendors and police officers. Research findings are presented through field-notes taken immediately either in the streets or as soon as possible upon leaving the research setting. All respondents were notified, plus they agreed to the methods used as well as to the goal of the study.
}

Although this paper showcases Mexico City as its primary case study, the information reported here could be of great value for an international audience, because it lies at the heart of a current sociolegal debate about the extent and nature of how the transmigration of some contemporary urban regulations, such as the 'New York model'4 and other initiatives, based on an especially aggressive law enforcement approach to a number of urban practices, affected specific places where the systematic occupation of public spaces represents the only opportunity to scrape out a living.

The remainder of this paper is structured as follows. In the first section, I present the research context, as well as discussing how street vendors and police officers have viewed street vending as an inalienable human activity, with the supervision and maintenance of public order in the downtown core area, up until the Giuliani intervention. In the second section, I present an account of how Giuliani's intervention was then enforced in order to clean up the streets of Mexico City's downtown core area. In the third section, I discuss how the effects of this process of sociolegal change have been interpreted in different and often contradictory ways. Finally, I will conclude with some comments regarding the limits and scope of this research.

\section{B. CONTEXTUALIZING RESEARCH}

The history of street vendors in downtown Mexico City, in terms of a complex and highly organized urban group, is too broad to summarize in a few paragraphs (Cross, 1998; Barbosa, 2008; Meneses, 2011). Nevertheless, suffice it to say that, at least since the 1930s, street vendors grouped themselves into numerous organizations with thousands of members and smaller organizations which were slowly incorporated into the group of popular organizations affiliated to the governing party (Davis, 1998). The degree, power and organization of these associations had, by then, increased.

This occurred such that, despite various efforts and strategies deployed by the authorities to end organized

\footnotetext{
4"The New York model is the approach to crime and disorder taken in New York City under Mayor Giuliani based on a particular interpretation of "broken windows" policies. This model justified an especially aggressive law enforcement approach to a number of urban social problems. It is this law enforcement approach that has been exported by leading transnational security consulting firms. In particular, former New York Police Chief William J. Bratton's consulting group, The Bratton Group, L.L.C., and Giuliani Partners have offered their expertise regarding crime and security to public officials in Mexico and South America." (Mitchell \& Beckett,2008:79)
} 
commerce on the streets of the downtown area, ${ }^{5}$ towards the end of the 1990s, and the beginning of 2000, authorities estimated that there were 705 formally constituted street vending organizations, of which 120 operated in the downtown Mexico City area, having more than 30,000 people in their ranks (GDFSISCOVIP, 2009).

As in other countries, in Mexico City, street vendors have attracted the attention of municipal authorities, journalists and academics concerned with maintaining the order on the streets (Bromley, 2001; Cross, 1998; Crossa, 2009), who have taken as a premise the often simplistic logic that assumes street vending to be entirely against the law, where people using the sidewalk in order to survive do not represent but 'empirical' variables for measuring the 'health' of the urban environment and its rule of law (Hayner, 1945; Lewis, 1997; Eckstein, 1998).

On the one hand, street vending has taken the form of a public problem largely determined by the urban elites who frequently identify street trade as a primary urban issue having implications on traffic and sanitation (Illy, 1986; Bromley, 2000); in other words:

"since street vendors are not evenly spread across the city, but concentrated in specific locations typically characterized as 'hot-spots' of pedestrian and vehicular congestion, the argument is that both the number of street vendors and levels of congestion are expected to further increase. This type of concentration would then cause traffic accidents, increase the levels of vehicle-generated air pollution and impede police efficiency" (Bromley, 2000:7)

On the other hand, street vending activities have been considered as those engaged in a more highly disreputable and often illegal set of social practices, where the massive and unlawful occupation of the public space is seen as the 'tip of the iceberg' of a more extensive pattern of illegal behaviors that include tax evasion and the sale of counterfeit goods. This

\footnotetext{
${ }^{5}$ In this sense, one of the most important and aggressive previous regulatory efforts deployed by the Distrito Federal authority was the incorporation of street vending as a particular criminal activity in the city's 1998 penal code. The penalizing of street vending "as the unlawful use of a public thoroughfare determined by an uncertain series of persons that benefited from assigning a public space to street vendors", served as a means to start, from January 1999 to June 2002, 2,431 penal processes against the leaders of street vendor organizations (PGJDF-OIP, 2008).
}

complex set of behavior also contemplates the bribes vendors are often required to pay to police and other law enforcers, as well as the opportunities they provide for pick-pocketing, snatch thefts or armed assaults (Nelken, 2006; Bromley, 2000). In sum, they represent:

"a set of less visible but more common
practices [than crime] that citizens
participate in, is the daily noncompliance
with the law [...] practices that, in a much
more extended manner, promote distrust
and, further, promote their own
acceptance, generating better conditions
for illegality" (Pérez-Correa, 2004).

Regardless of the great criticism this social practice have received throughout history, it is also true that there is little, if any, thought given to the fact that their organized, massive, and systematic occupation of the downtown streets constitute them as a sort of 'eyesupon-the-streets' (Jacobs, 1992). ${ }^{6}$

Indeed, throughout the middle of the 20th century, several social researchers documented how the presence of merchants in the historical downtown area of Mexico City was accepted by residents who "take great pride in their ability to protect themselves [...] because the informal ties among vendors and neighbors-in the eyes of many-keep theft and other problems of concern to them at a minimum" (Eckstein, 1988:262). In a way, this order was a product of the establishment of a series of agreements between the political authorities and the population; agreements in which even the sale of illegal products was tolerated in exchange for having street vendors inform the police of other illegal activities happening in the downtown area: "Reflecting the close ties policemen have
with the community, people living and
working in the streets were familiar with
the local police to the extent that they hide
stolen merchandise when they see the
police approaching them. When goods
were stolen from my car I had the
opportunity to observe relations between
the police and street vendors. I reported
the theft to the market administrator, a
retired policeman. Since I was an

\footnotetext{
${ }^{6}$ As noted by Ranasinghe (2012:72-3): "For Jacobs, the more people are in public, the opportunities for crime and disorder are drastically reduced, given that people act as the 'eyes and ears' of the street. In other words, natural surveillance is increased when people take to the street."
} 
American and a personal acquaintance of his he assigned the police to my case, even though the merchandise was not valuable or easily identifiable. While waiting for the police, I saw a large crowd suddenly gather around the police to find out what case they were beginning to investigate. Once the police learned what had been stolen from me, they visited certain houses near the market where thieves were generally known to store such goods before selling them in the second-hand markets". (Eckstein, 1988:51)

In this sense, it is important to note that, through those days, street vendors were not only in risk of being apprehended by the police, but also of having their money or illicit goods stolen by others. Indeed, during the first half of the Twentieth century, the areas of Mexico City with the highest percentage of conventional criminality tended to be located near the historical downtown area (Hayner, 1946). In other words, we may hypothesize that because of the criminal nature of this part of the city, street vendors were constrained to cooperate with the police to maintain public order, in order to prevent to be punished or to be stolen. In the contemporary context, there are numerous reasons to suggest that street vendors would also organize to counter this dynamic. ${ }^{7}$

Of course, it is hard to understand whether these arrangements constructed, among the $20^{\text {th }}$ century, between street vendors and police officers still work in a City that has increased its population seven times in 50 years and has undergone profound changes in its political system (Azuela, 2005). However, during my walkthroughs on the downtown streets and the interviews with the vendors, I could verify that maintaining security and order was a criterion that greatly determined the way in which the downtown street vendors organized themselves up until the Giuliani intervention. According to my interviews, the greater part of the organizations shared a system of private lookouts and informers who were paid for keeping the streets safe:

\footnotetext{
${ }^{7}$ As Wacquant (1999) and Bourdieu (1999) note, one of the most perverse effects of the spatial coincidence between crime and urban poverty could be the one of considering that the urban poor are constitutive elements more than the victims of crime. This presupposes forgetting, both institutionally and academically treat the population that inhabits and day-to-day must face those delinquent activities and develop strategies, links and mechanisms to deal with
} a situation in which it has been condemned to live.
"Look at these streets full of thieves. I live here, but no one hurts you if you know how to care for yourself. In my case, and I can tell you that in all the other organizations, we hire caretakers that not only look out for the space, that you do not extend your post, that no buckets or other obstacles are placed, but also that order is kept. As I am from the neighborhood, I see people who are just out of jail, and I tell them come over, l'll give you a job. I take them that way, and well, their function is clear: if they see a thief, they hit him and tell him: go the fuck somewhere else, not here" (SV, 10.08.07)

In part, the logic of this cooperation between street vendors and police appears to be founded on purely commercial logic:

"The authorities have always wanted to remove us from the streets. They have accused us of selling illegal products, drugs and weapons. But they have never found anything. We are poor people, and we do sometimes sell pirated goods, but nothing more. If you ask me, is there any place that sells drugs on the street? I could not answer. But not here, because we know that if we only give them one pretext they will take us away. It is so much so that we ourselves help keep our streets in order. Imagine, if for earning a few extra pesos, we would leave thousands of families without resources" (SV, 13.02.08).

Nevertheless, for some police officers, the fact that the street vendors represent a backdoor method of maintaining security and order, was consistent with a particular conception of sociospatial order. This tendency is marked by the opportunity of relying on a greater number of eyes and ears on the street:

"Delinquency moves because of the amount of people. If there are a greater number of people in the downtown area, it is logical that there would be more crimes. But because of that it was easier to solve crime when the street vendors were around. With so many people, someone told you who the criminal was and where he had run to. In other neighborhoods that 
are apparently calmer, it is more difficult because there are less people, which would mean a smaller number of witnesses." (P. 13.11.09)

$\mathrm{Be}$ it as it may, what appears to be in consensus for both the police and the merchants, is that the overwhelming presence of street vendors in downtown Mexico City represented a tangible means to keep the place safe and under surveillance. This does not mean that the population does not see street vendors as a sort of daily obstacle, mostly in terms of transit and the cleanliness of the area, ${ }^{8}$ while it does mean that in spite of the discomfort they created, street vendors were (self-)conceived as a public presence that guaranteed safety in the downtown streets. In this way, the presence of downtown street vendors appeared to guarantee one of the proposals put forth by Jacobs when imagining a city street equipped to handle strangers, and to establish a safety asset in itself, out of the presence of strangers: they worked as eyes upon the street "eyes belonging to those we might call the natural proprietors of the street [operating] with greater or lesser success through a web of reputation, gossip, approval, disapproval and sanctions" (1992:51).

However, according to the authorities, towards the end of the first decade of 2000 , the historical downtown core of Mexico City became the area with the highest crime index-24.5\% of the 24,975 total crimes registered in the whole city (PGJDF, 2006). ${ }^{9}$ Furthermore, a total of 3,000 prostitutes, 30,559 street vendors, and 3,050 street merchants (supply carriers, ticket sellers, shoe shiners, musicians) work on the streets daily among the yet undetermined number of homeless who lived on the streets of the zone (GDF, 2008). In Maureen Casey's words, managing the zero tolerance project, and the person who was previously responsible for the operations and administration areas of the New York police during the Giuliani administration, these elements configured downtown Mexico City as the main testing area for Mexico and Latin America to try out the crime fighting program proposed by Rudolph Giuliani's team (La Jornada 22.11.02).

\footnotetext{
${ }^{8}$ For example, a survey performed by Gobierno del Distrito Federal, in 2007, indicated that $43 \%$ of visitors to the downtown area did not feel comfortable because the sidewalks were occupied by street vendors (GDF, 2008).

${ }^{9}$ If only to get a sense of proportion on this official estimate, one should consider the fact that Mexico City has a surface area of 1,485 square kilometers, but the downtown area is a mere 9.1 square kilometers. See: www.centrohistorico.df.gob.mx/fideicomiso/ [retrieved on 12.05.12]. This implies that, at least from the official standpoint, nearly one in four crimes committed in Mexico City took place in $0.006 \%$ of its surface area.
}

Causality was never proven, but the spatial coincidence between crime and street-level economic activities was rapidly translated to a more aggressive mobilization of the law against street commerce. According to Joel Ortega the then Secretary of Public Security, street vendors not only conveyed the image that the law was not being enforced in downtown Mexico City, they also promoted the proliferation of other illegal activities, allowing criminals to use street vending sites to wait for the opportune moment to carry out their activities, and at the same time stay hidden from police vigilance (GDF-COM. SOC, 2008). In other words, urban authorities saw the presence of merchants along the streets 'as a threat to their Panopticon-like control' of the public order (Nelken, 2006:300). My research was conducted at the time the enforcement of this strategy really began to get under way. The remainder of this paper seeks to show whether the overbearing implementation of this process reconfigured the social order in the city's downtown core area, and what this can tell us about the effects of the broken-windows policy in a space where, for decades, street commerce has been clearly connected to generating the city's street culture.

\section{THE ‘GIULIANI PLAN’ FOR MEXICO CITY}

As in many other Latin American countries, ${ }^{10}$ starting in the first decade of the $21^{\text {st }}$ century, a group of businessmen in the Mexico City area, joined by the local police SSPDF [Secretaría de Seguridad Pública del Distrito Federal] hired Rudolph Giuliani as an international security consultant. The reasons for this action were that he would design an innovative set of security strategies and police practices with the purpose of providing a remedy for the crime problems that the Mexican capital was allegedly experiencing (Davis, 2007; Mitchell \& Beckett, 2008; Campesi, 2010). Thus, by the end of 2002, Giuliani Partners signed a US $\$ 4.3$ million contract to advise Mexico City officials in their efforts to reduce crime (Mitchell \& Beckett, 2008). The advice consisted of a 146-item proposal document on crime policy, and power reforms for the police (SSPDF, 2003). Even though one of the main contributions of the report was the new policing styles adopted by the SSPDF, its principal recommendation was to reassess the whole management of the public urban environment on the

\footnotetext{
${ }^{10} \mathrm{An}$ analysis on the relation that the Giuliani intervention has with other similar processes experimented in other cities can be seen in (Mitchell \& Beckett 2008; Campesi, 2010).
} 
basis of the celebrated broken-windows theory, thereby removing every sign of urban disorder not only from the downtown core area, but also in other upper-class and middle-class neighborhoods (SSPDF, 2003:36).

The so-called Giuliani Report on Mexico City, specifically indicated that people should be removed from the public environment if, on account of their way of life or appearance, they could come across as 'bearers of urban disorder' and thereby prove, or pose a threat to encouraging more serious crimes because of their presence. It also made explicit reference to the whole social universe that 'uses public spaces as a place to live and work' (SSPDF, 2003:39). This scope would include prostitutes, squeegee men, illegal parking attendants, small-time peddlers, street vendors and beggars who lived on the streets of Mexico City. Legal enforcement strategies to 'clean up' the public space, therefore, adopted new forms in keeping with the Giuliani Group's advice for the City. In 2004, the City issued a new 'Law of Civic Culture' [Ley de Cultura Cívica], which included several misdemeanors, many of them punishable with up to 36 hours of detainment. ${ }^{11}$ The new transgressions were intended to curb a wide range of behaviors that, according to the new law: 'do not constitute crimes but do, however, undermine civic harmony in a way that is damaging not only to citizens in their persons but also to collective goods, a place's respectability, public tranquility, and to the safety of citizens and the urban environment' (GDF, 2004).

As one of the anonymous reviewers have noted, for some authors, this legal reform has been embedded into a particular form of neoliberal urbanism where the aim of harsh policing methods is to create the conditions for redevelopment and gentrification (Campesi, 2009); an ideal that has been mirrored, in this case, by a specific policy oriented to "revitalize and beautify the streets, buildings and central plaza of the city's Historic Center" (Crossa, 2009). However, although this interpretation is possible, what it is important to note is that in spite of its cost and the promotion it received immediately following its proclamation, the Giuliani Group intervention seemed doomed to reproduce the functions of the old urban ordinances that regulated life in the streets of the city

\footnotetext{
${ }^{11}$ From earlier times, the local authorities had offered their fascination for the repressive dimensions of the law as a way to solve the City's problems. As noted by Mitchell \& Beckett (2008:98), "Even before the release of the [Giuliani's] report, the Mexico City Legislative Assembly, inspired by the spirit of 'zero tolerance', toughened penalties for a number of minor offenses and mandated that those who commit petty theft (including snacking on store food while shopping) receive at least six months in jail."
}

(CDHDF, 2005:32). In fact, as early as 2004 the arrests made under the purview of the Law of Civic Culture accounted for $75 \%$ of all the arrests made in the city (López Ugalde, 2003: 15; Azaola, 2006: 27, cf. Campesi, 2010:460) among which the predominant ones were consuming alcohol in public thoroughfares $(56 \%)$, followed by drug related activities (19\%), urinating in public $(9 \%)$, improper use of thoroughfares $(8 \%)$ and acting against social harmony in public places (4\%) (CDHDF, 2005). It seems that it was because of this that it became necessary to give it a much more concrete function and, above all, scale down the possibilities of putting it into practice with the objective of solving specific urban problems (SSPDF, 2007). ${ }^{12}$ This translated into an intensive mobilization of the law against more than 30,000 street vendors that worked in downtown Mexico City (Meneses, 2011; Silva, 2010). The strategy to remove street commerce from the downtown area was structured in three steps:

- In the first place, at the beginning of 2007, the authorities decided to cancel all municipal permits that allowed a determined number of subjects to involve in commercial activities on downtown streets $(\mathrm{N}=2,770)$. This had, as an immediate effect, the administrative proclamation that all commerce taking place on the streets in the downtown area is illegal (GDF-OIP, 2008).

- $\quad$ Secondly, on October 12 th, 2007, 2,000 police officers were deployed onto the downtown streets with the purpose of preventing the vendors from posting and setting up their wares (El Universal, 10.10.07; La Jornada, 12.10.2007).

- And thirdly, the cancellation of permits for commerce in the downtown area, in conjunction with the police deployment on the streets, resulted in a substantial increase in the mobilization patterns of the Ley de Cultura Cívica against street vendors who worked the area, going from 2,389 detained vendors in 2004-the year in which the law was proclaimedto 28,842 in 2008 (GDF-CJDF, 2009).

\footnotetext{
${ }^{12}$ Mitchell \& Beckett (2008:97-98) stated that the presence of street vendors in Mexico City streets not only appeared as a challenge to local authorities and their new security strategies, but also for the efficacy of the Giuliani model "The long-term impact of Mexico City's consultation with Giuliani Partners on crime policy is unclear. On the one hand, many of Giuliani Partners recommendations appear to have been largely ignored. Window washers and mobile street vendors, for example, continue to work in the streets without substantial risk of arrest. On the other hand, some of the recommendations were implemented: the police placed "panic buttons" on city buses and installed surveillance cameras in high crime areas. Bail was also increased for many offenders, thus exacerbating the problem of jail overcrowding".
} 


\begin{tabular}{|c|c|c|c|}
\hline & & \multicolumn{2}{|c|}{ Period } \\
\hline & & $\begin{array}{l}\text { Before mass legal enforcement } \\
\qquad(2005-2006)\end{array}$ & $\begin{array}{l}\text { After mass legal enforcement } \\
\qquad(2007-2008)\end{array}$ \\
\hline \multirow{2}{*}{ Street vendors detained } & Observed frequencies & 31,010 & 53,620 \\
\hline & $\%$ & 36.60 & 63.40 \\
\hline \multirow{2}{*}{$\begin{array}{l}\text { Other misdemeanors } \\
\text { (prostitution, consuming alcohol in } \\
\text { public thoroughfares, urinating in } \\
\text { public places) }\end{array}$} & Observed frequencies & 2,317 & 3,440 \\
\hline & $\%$ & 40.20 & 59.80 \\
\hline \multirow{2}{*}{ Thieves reported } & Observed frequencies & 2,412 & 1,788 \\
\hline & $\%$ & 57.40 & 42.60 \\
\hline \multirow{2}{*}{ Delinquents detained "red-handed" } & Observed frequencies & 6,055 & 8,768 \\
\hline & $\%$ & 40.80 & 59.20 \\
\hline Source: GDF-SSP/PGJDF (2010) & $x^{2}=799.1$ & $D f=3$ & $p<0.05$ \\
\hline
\end{tabular}

Figure 1: Patterns of legal mobilization before and after the Ley de Cultura Civica massive deployment".

Figure 1, has been constructed following Guerette's (2009:6) recommendations for analyzing the displacement of crime after the implementation of a given policy. Unfortunately, data developed by Mexico City's authority does not have the level of accuracy to follow the whole model. However, I have tried to include the most relevant information needed. Here, categories included are (1) street vendors detained, that represents the total amount of street vendors detained in the downtown core during the period reported; (2) other misdemeanors, that represents the total amount of prostitutes, people consuming alcohol in public thoroughfares or urinating in public places, detained in the downtown core during the period reported; (3) thieves reported, which refers to the entire number of thieves registered by authorities in the downtown core during the period reported; and, (4) delinquents detained "red-handed", which refers to the whole number of delinquents caught "red-handed" in the downtown core during the period reported.

As Meneses has stated (2011), from then on, the authorities started to publish results about the functionality that the systematic use of police force had against the street vendors in downtown Mexico City. Thus, on January 14, 2008, The Public Security Secretariat announced:

"Three months from having started the Centro Historico operative where informal commerce was removed from the first section of the city, the Secretaria de Seguridad Pública del Distrito Federal (SSP-DF), has detained 679 presumed criminals and removed seven thousand eight hundred and ninety six street vendors, which has amounted to a $27 \%$ reduction of the crime index in this zone" (SSP-DF, Comunicado 80/08).

And by April 2008, Joel Ortega, the then Secretary of Public Security, declared:

"From October 12 of last year, when the streets of the city's downtown area were cleaned, to date, crime has decreased by $32 \%$, the most serious crime being the

\section{one of pick-pocketing" (El Universal, 08.04.08).}

In some ways, this strategy resulted in making the detention of vendors the main task of the police in the streets of the downtown area of Mexico City, to such a degree that only from January to March of 2008, the number of street vendors represented $93 \%$ of all those detained by police in this space. Nevertheless, at least in the short term, the withdrawal of vendors from the streets of downtown Mexico City did not seem to ameliorate crime patterns in that area of the city. On the contrary, the actions taken by the administrative authority ended up reinforcing the erstwhile character of the zone as the most crime-ridden area in the city, with a total of 5,978 crimes registered at the end of 2009; this is to say, only $2 \%$ less than those registered in $2006(\mathrm{~N}=6,109)$ (PGJDF, 2009).

\section{MEASURING THE SUCCESS}

As noted by Zimring (2006:141-143), another way to qualitatively explain variations in the criminal activities associated with the public manifestation of certain practices considered as 'disordered', is to approach the 'degrees of visibility' relating to those 
places where a crime occurs (visible vs invisible crimes). ${ }^{13}$ Unfortunately, data reported by police officers in Mexico City is not recorded with this level of accuracy. However, if we take into serious consideration the official proposition that pick-pocketing was the most serious crime perpetrated by streetvending activities in the downtown area (El Universal, 08.04.08), then we can expect that the withdrawal of vendors from the streets of downtown Mexico City did at least ameliorate the patterns of pick-pocketing in that area of the city.

Let us compare the distribution of street vendors detained in Mexico City's downtown area with the number of pickpockets reported in the area, before (2005-2006) and after (2007-2008) the Ley de Cultura Civica was extensively deployed. We find that the observed frequencies present a considerable and statistically significant difference. Indeed, for registered pick-pocketers, this difference reached 624 thieves being reported. Furthermore, the capacity to arrest delinquents in the zone red-handed appears to have been affected by the wholesale removal of street vendors from the city's downtown area, to such a degree, that by 2007-2008, the observed frequencies presented a $(+2,713)$ difference with respect to the past period (2005-2006).

In other words, data presented suggests that the substantial increase in the mobilization patterns of the Ley de Cultura Cívica against street vendors did really affect the criminal behaviors it was trying to modify, thereby strengthening the character of street vendors as 'constitutive elements' of crime and disorder in the area. Furthermore, it also suggests that a more aggressive legal enforcement against specific small infractions (i.e., street vending) will lead to a higher level of delinquents arrested under flagrancy. And that this higher level of arrests, in turn, may also lead to a lower level of thieves reported.

Nevertheless, in the same merchants' voices-now withdrawn from the streets-this apparent increase in the number of delinquents caught red-handed in conjunction with the diminution of pick-pocketing registered in the streets, does not necessarily imply that such withdrawal had contributed to the authority's

\footnotetext{
${ }^{13}$ Of course, as Zimring also notes, this method could encounter many problems in measuring the causes of criminal dynamics, since "the governmental and social factors that influence crime rates over time are not agreed on, and the magnitude of influence of potential causes is also very much on dispute" (2006:143).
}

capacity to police the city's downtown area effectively and efficiently. On the contrary, it may mean that the police have experienced more difficulty in registering common crime in the area (i.e., pick-pocketing) while, at the same time, other types of crimes have started to rear their ugly faces on the streets (i.e., drug sales) (Muller, 2013). This would explain why the total number of crimes registered has not presented great variations during the period under study:

"It is complicated. In my case, I never tolerated drug sales or crap because they only make the place hot, and in the end everybody loses. Before, we even helped the police watch, so as to keep the streets crime free or to catch the criminals and report the crime to the authorities. [...] But of course, now there is who sells drugs, for example, there are some that were government people and now [that we were removed] they sell drugs over there, near Templo Mayor, and they then get aggressive because they want the streets for themselves, no? With their guns and everything, but, well, up to now the consequences have not become too great. I talk to the municipal authorities, but it is like talking to deaf people."(SV, 05.08.09)

Even some policemen who were interviewed shared this viewpoint to such a degree that they considered the general relocation of the street merchants represented a break with the balance that, for years, has preserved the order in the streets of the city's center:

"The withdrawal of street vendors was an imbalance. The city is no longer balanced. If a thief came, the vendor told you who it was. Why? Because he was protecting his business, he who is interested in that tells you: 'you know what, it was him'. Insecurity has grown, if you remove the vendors the thieves will be there waiting, give me your coat, your cell phone, every time they remove street vendors it will happen, the streets are lonely and dark, they see you and the thief waits for you." (P. 20.10.08)

Evidently, determining the true implications of the opinions expressed by the merchants who were 
removed from the streets ${ }^{14}$ is complicated; however, what is important to be stressed here is that under the approach proposed by Giuliani for Mexico City, downtown street vendors not only became the main social group castigated by this zero tolerance environment, but also this initiative generated their displacement to less secure spaces where they themselves became more likely to experience the violence and crime that the state intended to counter.

Indeed, in an attempt to minimize their risk of being apprehended, the reality of the situation is that street vendors-now retired from the main downtown streetshave been forced to sell their wares on the sly and run if the police came (Crossa, 2009). In addition to this, they have become objects of greater highhandedness and police abuse to such a degree that the Local Human Rights Commission was obliged to emit 16 recommendations against the local police for atrocities committed against street vendors in the downtown area in the 2004-2008 period (CDHDF, 2009). Besides, the vendors were unwittingly made targets of organized crime spearheaded by organized crime groups that extort the helpless displaced vendors. In fact, for 2010, the city police reported that there were 1,290 cases between January and June of that year, in which displaced street vendors reported cases of extortion and "right of land use" being charged by organized crime. This works out to 6.1 cases of extortion reported every day, of which 715 were completely credited ( $\mathrm{La}$ Jornada, 27.09.10). Thus, considering the aforementioned numbers, it can be said that the visibility of crimes in the downtown area may have been reduced as a result of the withdrawal of vendors from the streets. However, it would seem that from the interaction between the police and street vendors in the public areas, this new equation in the streets represented a disequilibrium with the order that took decades to materialize, and it also implied a kind of invitation for new, and probably more difficult to prevent

\footnotetext{
${ }^{14}$ Regardless, it is important to point out that, also in the mid 2011 , the local crime cartography -elaborated by the same Public Security Secretariat (Secretaría de SeguridadPública del Distrito Federal)- revealed the streets of downtown Mexico City, as the zone where the most pick-pocketing occurred in the whole city (El Universal, 08.04.11). Furthermore, in the words of a local congressman, even if the intense police work that has been done in the downtown area could be translated into a reduction in high impact crime-such as robbery- these advances, have not stopped the increase in other types of crime such as home break-ins or theft in the subway system in the south of the city. Thus, the idea that a greater concentration of police in one area -the city's downtown- and directed towards a specific population -street vendors- aiming to prevent particular criminal behavior -theft- could also displace criminal activity toward other spaces and other types of people and goods (ALDF, 30.03.2010).
}

illegal activities, like extortion or drug selling, to take place.

\section{E. DISCUSSION}

According to some authors, the limited success that the implementation of Giuliani's recommendations has had in Mexico City resembles the tale of an announced failure. In greater measure, the explanation offered for this failure has been the apparent lack of respect for the law by the authorities themselves, as well as the population that constitutes Mexico City (Valenzuela, 2004; Zacseski, 2010). In the opinion of some other authors, the Giuliani Plan has not failed; rather, it has been unduly overvalued by local authorities (Arroyo, 2003).

From a more general perspective, this dualistic interpretation of the broken windows effects in Mexico City suggests that "contrary to the claims of broken windows advocates, what constitutes disorder is far from obvious" (Muniz, 2011:19). Here, it seems that the introduction of Giuliani's conception of the broken windows argument in Mexico City, caused the local authorities to define street vending activities as a source and cause of disorder and crime, thereby removing those networks of informal social control that had functioned for decades in the historical downtown area.

Street vendors and policemen became exposed to a new way of thinking while working the streets, thus reinforcing their character as people who are condemned to supervising the margins of the urban order. But, the emergence of this new order could result in the problem of disturbing former guidelines that had structured street life for decades (Muniz, 2011)

Here, the axis and networks of past and present ways of street order have involved a variety of actors and agencies who often work with shared purposes but with different rationales. No doubt, the idea was to deter crime, but crime is also a contested social construction with "no necessary stopping-off place. We deal with [it] also in the shadow of the knowledge that 'crime' does not only mean local nuisances, grievances and troubles, but also means things that are extreme, bizarre, arcane, menacing" (Sparks, et al. 2001:887).

Nevertheless, a few authors have reflected on the way the application of these 'zero tolerance' policies impacted over and were received by the groups that 
make their living in the public urban environment of Mexico City. As Muniz also noted, there is very little firsthand qualitative work on broken windows, particularly outside of North America where policy designers instituted the policing method (2011:7). Therefore, it seems necessary to identify the general patterns in the way that these 'zero tolerance' policies have impacted over and are received by the societies in which they are intended to work.

Accordingly, a considerable part of the contemporary sociolegal literature agrees on the fact that control policies, like the ones deployed by Giuliani in New York City, which were designed and implemented using the 'zero tolerance' approach, have had three main but interrelated consequences. The first of these is the conceptualization of work that takes place on the street as not merely a troubled activity [since] it is capable of considerable disorder, thus, constituting street-level activities as the main subject for enhanced regulation, sanctions and asset seizures. For instance, since, in Giuliani's first year as mayor, "arrests for illegal vending increased by 38\% [in New York]; summons for illegal vending increased by $40 \%$ and seizures of vendors' property increased by $37 \%$ " (Mitchell \& Beckett, 2008:90).

A second effect would be that the exacerbated emphasis on the persecution of established street activities has caused the removal of specific social groups to less secure spaces where they themselves are more likely to experience the violence and crime that the state wished to counter. In fact, in the case of prostitution, it has been noted that "there is a synergist relationship between an increase in law enforcement activity and violence against sex workers, including violence by clients, drug dealers, police [and so on]. In New York City in 1996 and 1997, as Mayor Rudolph Giuliani organized a campaign to "improve quality of life" by increasing the number of arrests of street people, social workers observed an increase in the number of rapes and murders reported by sex workers from one to two per month to five to eight per month" (Alexander, 1998:78).

A third effect consists of a combination of a more aggressive policy of police persecution accompanied by the greater risk of being an object of criminal activity. These strategies have had an influence in the patterns and daily practices of the targeted populations. Once more the case of prostitution in New York City may illustrate the point. "In those two years [19961997] a number of street workers began working out of vans and/or using beepers to reduce the risk of arrests. Others migrate to work in other neighborhoods [...] where they faced a sharply increased risk of assault" (Alexander, 1998:78).

This set of effects appears to have been replicated in the Mexico City case, where the cancellation of permits for commerce in the downtown area, in conjunction with the police deployment on the streets, resulted in a substantial increase in the mobilization patterns of the legal system against street vendors who worked the area, thereby displacing them only to be relocated in less secure spaces where they themselves were more likely to experience the violence and crime that the state intended to counter.

In this sense, to identify the reproduction of patterns similar to those of the broken windows effects in contexts other than New York City, this could create some possibilities for the analysis and systematic comparison of the effects generated by these initiatives in different contexts. However, the identification of these common patterns does not imply the presumption that says initiatives have been applied on the same terms, or have confronted the same challenges. As Campesi notes "policy transfer is not a pure import-export operation. The original [Giuliani's] model stands affected by the political and structural conditions of the place where the imported policy is to operate" (2010:468). In other words, as one street-level policemen mentioned:

"Yes, Giuliani came here [to Mexico City]
and recommended many things. For
example, he suggested our salaries
should be increased because our
colleagues in New York earn a thousand
times more than we do, and in dollars, but
they did not increase them. But, what did
happen? Well, that they sent us to the
streets to remove street vendors. This is,
they hired that person so he would tell
them what to do and then they did only
what was convenient to them" (P.
17.11.2008).

Accordingly, some authors have stated than "the ambiguity of broken windows should be addressed with efforts to define disorder with greater accuracy through the systematic study of the people who may increase or decrease safety" (Duneier, 2001:298-315, cf. Muniz, 2011:8). However, as some other authors suggest, "sociological knowledge is somehow a more just or 
component method for determining social hierarchies in a context where governmental and social factors that may influence urban order are not agreed on, and the degree of influence of potential causes is also very much on dispute" (Zimring, 2006:143; Muniz, 2011:8).

Such indeterminacy reflects a conflictive relation between two ideal types of urban society (Pavarini, 2009). On the one hand, to imagine people working on the streets as to be constitutive elements of crime and disorder means to conceptualize the city as a distrustful space where people in public places are not able to get along without the supervision of the state. On the other hand, to depict people working on the streets as an informal mechanism that regulates the spontaneous interaction between individuals involving public space means to endorse the city as a huge community where people may tend to look after each other and share specific codes of behavior and social values.

Therefore, the decision that the Mexico City authorities took in conceptualizing street vendors as potential criminals allowed us to get closer to the methods by which visible and public manifestations of certain practices considered 'unorganized' had been overvalued under the explicative potential of the 'broken windows' theory. Nevertheless, this approach, based on an empty space where the law is fully complied with, appears to prove its limitations as a means to signify everyday urban practices as elements to define an urban space. In other words, a question that this approach does not answer is: Why, if the street vendors were constitutive of criminal activities in Mexico City's downtown area, did their withdrawal not reflect in a significant reduction in the number of crimes registered in the area? The response to this may be the fact that a deteriorated urban space, at least to the eyes of those who are in charge of its administration, has no "multiplying effects on the levels of objective security that are present in said place [...] but a legitimizing effect on the expulsion and objective neutralization of social groups [particular ones] in some zones of the city, [...] a cosmetic operation paid for at a very high price" (Pavarini, 2009:236).

The insistence of street vendors and police enrolled in supervising the historic downtown area for establishing the 'eyes on the streets' character of street vendors allowed us to approach the definition of another model of society. This is based on a particular conception of the social interaction that observes crime and urban disorder as a social fact structured by a spatio-temporal confluence of at least two actors (a possible law-breaker and a probable victim) relating to the streets. Moreover, there is an unanswered underlying question in this case: Why, if street vendors also worked as eyes on the streets of the historic downtown area of Mexico City, did crime not increase to an appreciable extent, when they were abruptly and collectively moved out from the public space? A possible explanation is that this specific type of informal regulation was directed "towards preventing and persecuting crime that is systematically present in public spaces (fights, pickpocketing) affecting specific areas [mainly the streets occupied by hawkers], but it is not prepared to deal with other more complex types of delinquent activities [i.e., extortion] that have come to break with the old adage of 'the opportunity makes the thief'" (Pavarini, 2009).

In any account, a statement that emerges from this discussion is that the relation between urban order and delinquency must not be seen as a unidirectional process; rather, it must be understood as a complex process in which a variety of social actors and factors can play an influential role. Accordingly, the findings presented here not only suggest the importance of carefully focusing on "how" broken windows policing programs are implemented, as suggested by Heinkle and Weisburd (2008), but they also imply that in those countries where street economic activities represent a predominant means of earning one's livelihood, the relation between order and crime may be more porous and indeterminate than is recognized by the majority of sociolegal studies developed around this topic. This opens up new avenues for analysis as well as a discussion on the limits and the actual reach that an especially aggressive law enforcement approach to a number of urban practices may have on crime.

\section{REFERENCES}

Alexander, P. (1998) "Sex Work and Health: A Question of Safety in the Workplace", JAMWA, 53 (2): 77-82.

Arroyo, Mario (2003), "Evaluando la 'estrategia Giuliani': la política de cero tolerancia en el Distrito Federal", USMEX 2003-04 WorkingPaper Series, Center for U. S.-MexicanStudies, University of California at San Diego.

Azuela, A. (2005) "Mexico City: The City and its Law in Eight Episodes, 1940-2005" In: Philippopoulos-Mihalopoulos, A. (2005), Law and the City, London: Routledge: 153-170.

Barbosa, M. (2008) El Trabajo en las Calles: Subsistencia y negociación política en la ciudad de México a comienzos del siglo XX, México: Universidad Autónoma Metropolitana.

Bauman, Z. (2000) "Social issues of law and order", The British Journal of Criminology, 40 (2): 205-221.

Beckett, K., \& Herbert, S. (2008) "Dealing with disorder: social control in the postindustrial city", Theoretical Criminology, 12(1): 530. 
Bliss, K. (2010) Compromised Positions: Prostitution, Public Health and Gender Politics in Revolutionary Mexico City, Pennsylvania: Pennsylvania State University.

Bourdieu, P. (1999) "Los efectos del lugar", In: Bourdieu, P. Et. Al. La Miseria del Mundo, Buenos Aires: Fondo de Cultura Económica: 119-124.

Bromley, R. (2000) "Street vending and public policy: a global review", International Journal of Sociology and Social Policy, 20 (1-2): 1-28.

Campesi, G. (2010) "Policing, urban poverty and insecurity in Latin America", Theoretical Criminology, 14 (4): 447-471.

Cross, J. (1998) Informal Politics: Street Vendors and the State in Mexico City, Stanford CA: Stanford University Press.

Crossa, V. (2009) "Resisting the Entrepreneurial City: Street Vendors' Struggle in Mexico City's Historic Center", International Journal of Urban and Regional Research 33.1:43-63.

Davis, D. (1999) El Leviatán urbano: La ciudad de México en el siglo XX, México: Fondo de Cultura Económica.

Davis, D. (2007) "El factor Giuliani: delincuencia, la "cero tolerancia" en el trabajo policiaco y la transformación de la esfera pública en el centro de la ciudad de México", Estudios Sociológicos, 25 (75): 639-681.

De Gaudemar, J. (1981) La movilización general. Madrid: La Piqueta.

Duneier, M. (2001) Sidewalk, New York: Farrar, Straus and Giroux.

Eckstein, S. (1998) El Estado y la Pobreza Urbana en México, México, Siglo XXI.

Guerette, R. (2009) Analyzing crime displacement and diffusion. Center for Problem Oriented Policing, Tool Guide No.10. Available at: http://www.popcenter.org/tools/displacement/

Gurr, T. (1976) Rogues, rebels, and reformers: a political history of urban crime and conflict.Beverly Hills, Calif.: Sage Publications.

Harcourt, B. \& Ludwig, J. (2006) "Broken Windows: New Evidence from New York City and a Five-City Social Experiment", The University of Chicago Law Review, 73:271-320.

Harcourt, B. (1998) "Reflecting on the subject: A critique of the social influence conception of deterrence, the broken windows theory, and order-maintenance policing New York style", Michigan Law Review 97: 291-389

Hartley D. (1999) Begging Questions: street level economic activity and social policy failure, Bristol: Policy Press.

Hayner, N. (1946) "Criminogenic Zones in Mexico City" American Sociological Review [microfilm]

Hinkle, J. \&Weisburd, D. (2008) "The irony of broken windows policing: A micro-place study of the relationship between disorder, focused police crackdowns and fear of crime", Journal of Criminal Justice, 36: 503-512.

Illy, H. (1986). Regulation and evasion: Street-vendors in Manila. Policy Sciences 19(1), 61-81.

Jacobs, J. (1992) The death and life of great American cities, Vintage Books ed.

James, Z. (2007) "Policing marginal spaces: Controlling Gypsies and Travellers" Criminology and Criminal Justice 7: 367-389.

Kubrin, C. (2008) "Making Order of Disorder: A Call for Conceptual Clarity", Criminology and Public Policy, 7: 203-214.

Lewis, O. (1997) Antropología de la Pobreza: Cinco Familias, México: Fondo de Cultura Económica.

Loukaitou-Sideris, A. \& Ehrenfeucht, R. (2009) Sidewalks: Conflict and Negotiation Over Public Space. Cambridge, Mass.: The MIT Press.

Meneses, R. (2011) Legalidades públicas: El derecho, los ambulantes y las calles del centro de la ciudad de México (1930-2010). México: Universidad Nacional Autónoma de
México, Instituto de Investigaciones Jurídicas/Centro de Investigación y Docencia Económicas.

Mitchell, K., \& Beckett, K. (2008) "Securing the global city: crime, consulting, risk, and ratings in the production of urban space". Indiana Journal of Global Legal Studies, 15(1): 7599.

Müller M-M. (2013) Penal Statecraft in the Latin American City: Assessing Mexico City's Punitive Urban Democracy. Social \& Legal Studies. 0964663913482932, first published on May 12,2013 doi:10.1177/0964663913482932

Muniz, A. (2011) "Disorderly community partners and broken windows policing" Ethnography, first published on December 22, 2011 doi:10.1177/1466138111424982

Nelken, D. (1996). "Immigrant beach selling along the Italian Adriatic coast: De-constructing a social problem", Crime, Law and Social Change, 45 (4-5): 297-313.

Ochoa, E. (2001), "Coercion, Reform, and the Welfare State: The Campaign against 'Begging' in Mexico City during the 1930's", The Americas: 39-64.

Patton, M. (1987) How to Use Qualitative Methods in Evaluation.London: SagePublications.

Pavarini, M. (2009) Castigar al enemigo: Criminalidad, exclusión e inseguridad. Quito: FLACSO.

Pérez-Correa, C (2004) "Desconfianza y Desobediencia: Discurso y Práctica del Derecho en México" Available at: http://www.law.yale.edu/documents/pdf/sela/CatalinaPerezC orrea_Spanish_.pdf

Piccato, P. (2001) City of Suspects: Crime in Mexico City 1900-1931, Durham: Duke University Press.

Ranasinghe, P. (2012) 'Jane Jacobs' framing of public disorder and its relation to the 'broken windows' theory", Theoretical Criminology, 16 (1): 63-84.

Roever, S. (2006) "Street Trade in Latin America: Demographic Trends, Legal Issues, and Vending Organizations in Six Cities" WIEGO Urban Policies Program.

Sampson, R. \& Raudenbush, S. (1999) "Systematic Social Observation of Public Spaces: A New Look at Disorder in Urban Neighborhoods", The American Journal of Sociology, 105(3): 603-651.

Scott, J. (1998) Seeing like a state: How certain schemes to improve the human condition have failed. New Haven: Yale UniversityPress.

Silva, D. (2010) "Comercio ambulante en el Centro Histórico de la ciudad de México (1990-2007)", Revista Mexicana de Sociología 02:195-224.

Sparks, R., Girling, E. \& Loader, I. (2001) "Fear and Everyday Urban Lives", Urban Studies 38 (5-6): 885-898.

Swanson, K. (2007) "Revanchist Urbanism Heads South: The Regulation of Indigenous Beggars and Street Vendors in Ecuador", Antipode, 39 (4): 708-728.

Valenzuela A. (2004), "La ley de la calle: inseguridad urbana y control social del espacio en la Ciudad de México", Journal of Latin American UrbanStudies, 6: 57-72.

Vázquez, E. (1998) Organización y resistencia popular en la ciudad de México durante la crisis de 1929-1932, México: Instituto Nacional de Estudios Históricos de la Revolución Mexicana.

Vázquez, I. (1991) El Abasto en la ciudad de México, México: Departamento del Distrito Federal.

Venkatesh, S. (2006) Off the books: the underground economy of the urban poor. Cambridge, Mass.: Harvard University Press.

Wacquant, L. (1999) "De Norteamérica como utopía al revés", In Bourdieu, P. Et. Al. La Miseria del Mundo, Buenos Aires: Fondo de Cultura Económica: 125-132.

Wacquant, L. (2001) Parias urbanos: Marginalidad en la ciudad a comienzos del milenio.Argentina: Manantial. 
Wang, D. (1998) "Street Culture: Public Space and Urban Commoners in Late-Qing Chengdu", Modern China, 24 (1): 34-72.

Wardhaugh, J. (2009) "Regulating social space: Begging in two South Asian cities", Crime, Media, Culture: An International Journal 5 (3): 333-341.

Wardhaugh, J. (2011) "Beyond the Workhouse: Regulating Vagrancy in Goa, India", Asian Journal of Criminology, 2011-03-30: Online first.

Wilson, J. \&Kelling, G. (1982) "Broken windows", Atlantic Monthly (March):29-38.

Zackseski, C. (2010) "Relatos sobre a consultoriaGiulianinaCidade do México. Umexemplo para o Rio de Janeiro?", Anais do XIX Encontro Nacional do CONPEDI, Fortaleza.

Zimring, F. (2006) The Great American Crime Decline, Cary, NC: Oxford University Press.

\section{Other Materials}

Comisión de Derechos Humanos del Distrito Federal (CDHDF), INFORME ESPECIAL sobre la situación de los juzgados cívicos del Distrito Federal durante el 2004, México, 2005.

Departamento del Distrito Federal, Codificación de las disposiciones administrativas vigentes cuya aplicación corresponde al Departamento del Distrito Federal, T. I y II. , México, Talleres Linotipográficos “Acción”, 1943.

Departamento del Distrito Federal, Memoria del Departamento del Distrito Federal (Septiembre 1939-Agosto 1940), México, Departamento del Distrito Federal, 1940.

Departamento del Distrito Federal, Memoria del Departamento del Distrito Federal (Septiembre 1942-Agosto 1943), México, Departamento del Distrito Federal, 1944.

Departamento del Distrito Federal-Dirección General de
Gobernación, Legislación del Departamento del Distrito Federal y la Jurisprudencia de la Suprema Corte relacionada con la misma. T. I, II y III, México, Talleres de Publicaciones Mexicanas, 1970.

Gobierno del Distrito Federal (2004) Ley de Cultura Cívica para el Distrito Federal.

Procuraduría General de Justicia del Distrito Federal, Reporte de actividades correspondiente al primer semestre de 2009.

Procuraduría General de Justicia del Distrito Federal, Respuesta a solicitud de información pública: 0113000018908.

Secretaría de Seguridad Pública del Distrito Federal, Comunicado 80/2008.

Secretaría de Seguridad Pública del Distrito Federal, Reporte Giuliani, México, 2003.

\section{News}

La Jornada (11.11.02) "Agreden ambulantes a familia".

Reuters-NPR (13.06.06) "Vendors Drive Mexico's 'Informal' Economy", Available at: http://www.npr.org/templates/story/story.php?storyld=548106

El Universal (12.03.07) "Piden que ambulantes instalen y quiten puestos".

La Jornada (12.10. 07) "Cumplen ambulantes y dejan libres las calles del perímetro A",

La Jornada (03.01.08) "Arrestan por 36 horas a toreros reincidentes".

Reforma (18.01. 10) "Secuestran a franeleros"

La Jornada (27.09.10) "Aumentan denuncias por extorsión contra ambulantes del Centro".

Received on 29-04-2013

Accepted on 30-05-2013

Published on 04-06-2013

DOI: http://dx.doi.org/10.6000/1929-4409.2013.02.19

(C) 2013 Rodrigo Meneses Reyes; Licensee Lifescience Global.

This is an open access article licensed under the terms of the Creative Commons Attribution Non-Commercial License (http://creativecommons.org/licenses/by-nc/3.0/) which permits unrestricted, non-commercial use, distribution and reproduction in any medium, provided the work is properly cited. 